\title{
Arteriovenous Fistula After Kidney Transplantation in University Hospital Centre Osijek
}

\author{
Anton Jurić ${ }^{1}$ (D) , Lada $Z_{i b a r}{ }^{1}$ \\ University Hospital Centre Osijek, Department of Diagnostic and Interventional Radiology, Osijek, Croatia \\ ${ }^{2}$ University Hospital Merkur, Department of Internal medicine, Division of Nephrology, Zagreb, Croatia \\ School of Medicine, University J. J. Strossmayer, Osijek, Croatia
}

\begin{abstract}
:
Aims: To examine the proportion of patients with thrombosis or surgical ligation of arteriovenous fistula (AVF) after kidney transplantation (TX) and to explore the time passed after the TX until the loss of AVF function.

Patients and methods: The study design was historical cohort study. The study included all 123 patients ( $57.7 \%$ men, median age 58 years, from 34 to 79 ) that underwent kidney TX in the University Hospital Centre Osijek during the first 10 years of practicing that kind of surgery in the hospital. The data on AVF function, thrombosis or ligation were undertaken from medical records, along with demographics (age, gender, time after TX). The data were presented descriptively and after statistical analysis that was performed using SPSS (version 17.0).

Results: FunctionalAVF immediately prior to TX was found in $78 \%$ of the patients. The AVF was still functional in $39.84 \%$ of all patients for 3 years (median, interquartile range, IQR $0-3$ ) after TX. AVF thrombosis happened in $17.89 \%$, while surgical ligation was performed in $20.33 \%$ of all patients. The most common reason for ligation was increased risk of heart failure (in $75 \%$ of the ligations), followed by aneurysmatic dilatation and arm swelling. Median time after TX to thrombosis or ligation of AVF was 2 years, IQR $0-3$. Thrombosis or ligations were significantly more frequent in women. The outcome of AVF after kidney TX was not related to the patient's age.

Conclusion: AVF after kidney TX often became nonfunctional, either after spontaneous thrombosis or after surgical ligation, which was required for increased heart failure risk in the majority of the cases.
\end{abstract}

KEYWORDS: arteriovenous fistula; kidney transplantation; thrombosis; ligation; heart failure

\section{SAŽETAK:}

ARTERIJSKOVENSKIH FISTULA NAKON BUbREŽNOG PRESAĐIVANJA U KLINIČKOM BOLNIČKOM CENTRU OsiJek

Cilj: Istražiti udio ispitanika u kojih je nakon bubrežnog presađivanja (transplantacije, TX) došlo do tromboze ili ligacije arterijskovenske fistule (AVF) te istražiti vrijeme nakon TX-a u kojemu je došlo do gubitka funkcije AVF-a.

Ispitanici i postupci: Istraživanje je ustrojeno kao kohortno povijesno istraživanje.Uključeno je svih 123 bolesnika (57,7 \% muških, medijana dobi 58 godina, od 34 do 79) kojima je bubrežni presadak transplantiran u Kliničkom bolničkom centru Osijek tijekom prvih 10 godina otkako se u toj bolnici vrši bubrežni TX. Iz medicinskih zapisa preuzeti su podaci o funkciji AVF-a, trombozama i ligacijama, kao i demografski podatci (dob, spol, vrijeme nakon TX-a). Podaci su prikazani deskriptivno i analitički, a statistički obrađeni pomoću SPSS-a (inačica 17.0).

Rezultati: AVF neposredno prije TX-a imalo je 78 \% bolesnika. Još uvijek funkcionira u 39,84 \% svih ispitanika, 3 godine (medijan, interkvartilni raspon, IQR od 0 do 3) nakon TX-a. Tromboza AVF-a je nastupila u njih 17,89 \%, a ligacija je izvedena u 20,33 \% svih ispitanika. Najčešći razlog ligacije AVF-a u našem istraživanju bio je srčano opterećenje (u $75 \%$ ligacija), zatim aneurizmatična dilatacija AVF-a te otok ruke. Vrijeme nakon TX-a do tromboze ili ligacije bilo je medijana 2 godine (IQR $0-3$ ). Tromboza ili ligacija bili su značajno češći u žena. Sudbina AVF-a nakon bubrežnog TX-a nije bila povezana s dobi bolesnika.

Zaključak: AVF nakon bubrežnog TX-a često postaje nefunkcionalna, nakon spontane tromboze ili kirurške ligacije, a koja je najčešće indicirana zbog srčanog opterećenja.

KLJUČNE RIJEČI: arterijskovenska fistula; bubrežna transplantacija; tromboza; ligacija; srčano zatajenje;

\section{OPEN ACCESS}

\section{Correspondence:}

Anton Jurić MD

juricanton5@gmail.com orcid.org/0000-001-8770-7268

This article was submitted to RAD CASA - Medical Sciences as the original article

Conflict of Interest Statement: The authors declare that the research was conducted in the absence of any commercial or financial relationships that could be construed as a potential conflict of interest.

Received: 28 August 2019 Received: 28 August 2019 Published: 27 December 2019

\section{Citation:}

Juric A and Zibar L. Arteriovenous Fistula After Kidney Transplantation in Clinical Hospital Centre Osijek. RAD CASA - Medical Sciences. $540=48-49$ (2019): 8-14. https:// dx.doi.org/10.21857/yrvgqtkdp9

Copyright (C) 2019 Juric and Zibar. This is an open-access article distributed under the terms of the Creative Commons Attribution $\mathrm{Li}$ cense (CC BY). The use, distribution or reproduction in other forums is permitted, provided the original au permitted, provided the original author(s) and the copyright owners( are credited and that the original publication in this journal is cited, in accordance whit accepted adacemic practice. No use, distribution or reproduction is permitted which does not comply with these terms. 


\section{INTRODUCTION}

The Arteriovenous Fistula (AVF) is a permanent vascular approach for patients with chronic kidney disease (CKD) in the form of a direct (subcutaneous compound between the radial artery and the cephalic vein on the forearm, but may be used and the blood vessels more proximal than the carpal joint or under the elbows) or of the indirect AVF (a compound between the artery and vein which is usually formed by a syntethic vascular implant), so-called. polytetrafluoroethylene graft (PTFE). The central venous catheter (CVC) is used in those patients who have exhausted other possibilities of permanent vascular access ${ }^{1-4}$.

$\mathrm{CKD}$ is defined as a reduction of renal glomerular filtration $<60$ $\mathrm{ml} / \mathrm{min} / 1.73 \mathrm{~m} 2$ of body surface area for three or more months. Diabetic and hypertensive nephropathy, glomerulonephritis, and autosomal dominant polycystic kidney disease are the main causes of CKD appearing in developed countries such as the United States, but also in many underdeveloped countries ${ }^{5,6}$. Clinical symptoms of the disease appear in the damage more than $80 \%$ of kidney function, or from the third stage of a disease. It manifests as anemia, weakness, fatigue, loss of appetite and nocturia. The final stage of the CKD is in fifth grade. Then there are various organic complications such as cardiovascular, digestive, neurological, hematological, endocrinological, etc. At this stage, life is unsustainable without replacing renal function by dialysis through previously created AVF or transplantation $(\mathrm{TX})^{7-10}$.

\section{REPLACEMENT OF RENAL FUNCTION}

Dialysis is the process of eliminating waste metabolites and excess water from the body. There are two methods of dialysis: hemodialysis (HD) and peritoneal dialysis (PD $)^{10}$. HD is a procedure that removes blood from the body, and purified through a filter out of the body, called dialyzer, and require repeated access to the bloodstream. HD-blood of the patient flowing through the tube connected AVF and through a dialyzer. During HD, heparin is used, a medication that prevents blood clotting inside the dialyser. Inside the dialyzer, a porous membrane made of separated blood fluid (dialysate) which is chemically similar to normal body fluids. The pressure side of the membrane where the dialysate is less than that on the side of the blood, allowing the liquid, and waste products harmful compounds in the blood cross the (filtered) through the membrane into the dialysate. Blood cells and large proteins are too large to pass through the small membrane cavities. The dialyzed (purified) blood returns to the patient's body ${ }^{10}$.

PD uses the peritoneum as a semipermeable membrane for the exchange of matter. It is based on pouring a solution containing electrolytes and glucose or icodextrin as the osmotic substances in the abdominal cavity, typically by gravity. Uremic toxins from the blood passes into the dialysate concentration gradient down the diffusion process, while the osmolality of dialysate determines migration of water. The tip of the catheter with numerous perforations is placed in a small pelvis and the outer part remains outside the abdominal cavity ${ }^{1-4}$.

TX is the best method of repleacing the renal function in the treatment of CKD. Often, a regular exacerbated renal function is achieved so that one transplanted kidney can completely replace the lost function of its own kidneys. Dialysis is usally necessary for the appropriate treatment and preparation of patients for TX and subsequent immunosuppression therapy, although TX can also be done without prior dialysis - so-called. preemptivni TX. Due to constant immune response to allograft kidney, lifetime is performed immunosuppressive therapy to prevent graft rejection ${ }^{11-17}$.

There are several chiral access options for HD: AVF, then AV graft or $\mathrm{CVC}^{18,19}$. In a study evaluating the quality of life in patients with AVF or AV graft, it was concluded that he was equal to or moderate $^{20}$. However, due to the blood flow of about $400 \mathrm{ml} / \mathrm{min}$ required for high quality dialysis, high passage and low incidence of infection, AVF is a better choice compared to $\mathrm{AV}$ graft or $\mathrm{CVC}^{18,19}$. It is most commonly used when kidney glomerular filtration is $<15$ $\mathrm{ml} / \mathrm{min} / 1.73 \mathrm{~m} 2$ of body surface ${ }^{21}$. It is created by a short joining of the arteries with the vein located mostly on the proximal part of the upper arm (cervical vein and radial artery or basal vein and ulnar artery $)^{18,19}$. The maturity for successfully performing subcutaneous AVF puncture is reached when arterial venous arterialization occurs due to the constant artery blood vessel. The vein grows and becomes visible on the $\operatorname{skin}^{22}$. The AVF's maturity can also be stimulated by compressing the rubber ball. Then it becomes large enough to accept a large blood flow of about $400 \mathrm{ml} / \mathrm{min}$ required for successful dialysis. AVF, as such, becomes mature for its basic function ${ }^{23}$.

\section{AVF COMPLICATIONS}

In recent years ischemic lesions that were caused by arterial phenomenon of "steal", have become more common in the elderly population with high morbidity accompanying vascular disease and diabetes patients. There are two forms of this phenomenon. The first is associated with the rapid flow in which AVF with very low resistance begins to "suck" the blood from the palmar arch and ulnar artery, creating a critical ischemia of the fingers. In theory, this type of lesion is relatively easily corrected by limiting the size of anastomosis and reducing the flow of fistula $a^{24,25}$. Since resistance goes with the fourth potency of the radius according to Poiseuill's law, only a drastic reduction of the lumen of the fistula will be effective. However, creating an effective and safe lumen is difficult and it poses a risk of low flow and possible thrombosis.

Harder, but unfortunately increasing frequency, is another form of the "steal" phenomenom and that in patients with low blood flow through the AVF. This form is primarily a result of stenosis of peripheral arteries, so even normal blood flow through the fistula will create a critical ischemia in the distal vascular pool. Preoperative monitoring helps to predict the risk of a potential low flow "steal" phenomena from the limited vasodilation of the palmar arch arteries, which is manifested by abnormally low postishemic diastolic flow after fingers pressing. There are several treatment options to eliminate this problem. One is to close the fistula and use CVC, and the alternative procedure was originally proposed by Schanzer et al. and has recently been renamed DRIL (distal revascularization-interval ligation, closure of distal part of revascularization) $)^{26,27}$. Cardiovascular diseases are the main cause of death in dialysis patients or patients with kidney transplants. In the case of renal TX, the AVF is left open because it is unknown how long it will take for a satisfactory kidney function to last. It is closed by ligation only in the case of cardiac failure, rapid blood flow through the fistula, complications at the entrance to the fistula itself or in case of aesthetic reasons. In the case of ligation, fistula loss occurs and can not be re-opened in case of repeated HD needs. Ligation is more common with fistulas on the upper arm because of the faster blood flow. Fast flow through AVF, greater than $2200 \mathrm{ml} / \mathrm{min}$ results in 
increased cardiac output, followed by cardiac failure, hypertrophy or left ventricular dilatation, increased diastolic pressure, pulmonary hypertension, cardiomegaly, distal ischemia, aneurysmatic enlargement etc. ${ }^{28-37}$. Rapid blood flow leads to damage to the AVF's blood vessel endothelium, which favors the development of inflammatory activity. This results in the accumulation of inflammatory mediators such as interleukin 2 , interleukin 6 , tumor necrosis factor alpha and C-reactive protein. They exacerbate the onset of heart failure and lead to an increase in mortality in hemodialysis patients ${ }^{38-44}$. AVF aneurysms usually result from the destruction of the blood vessels wall and the replacement of the biophysically less valuable collagen tissue. Once aneurysm occurs, Laplace's law predicts a spontaneous tendency of progression, because pressure applied to the walls of blood vessels becomes larger with an increased diameter of the aneurysm. The prerequisite for creating aneurysm is usually stenosis and prolonged increase in blood flow pressure. The main complications of aneurysm are rupture, infection (resulting from intraaneurysmatic thrombi), and in rare cases anterograde or retrograde emboli ${ }^{45}$.

In addition to the AVF's surgical closure, spontaneous occlusion or thrombosis may occur in the arteries, anastomoses themselves, or usually veins. The most common cause of AVF occlusion is the diameter of the cephalic vein and radial artery. The smaller it is, the greater the risk of occlusion. In addition, high blood pressure and high levels of parathyroid hormone also increase the risk of occlusion. Occlusion can also be due to intimal hyperplasia of blood vessels during the anastomotic surgical procedure ${ }^{46,47}$. Thrombosis can be caused by stenosis itself, wearing inappropriate clothing, and aneurysmatic enlargement, causing turbulent blood flow, arterial blood supply and arterial hypotension. Pathophysiology based on stenosis is a blood flow turbulence that activates platelets and endothelial cells. In this context, the role of platelet growth factor ${ }^{48}$ was also determined. The final trigger that causes thrombosis is critical reduction of blood flow through the fistula. Many studies prove that low flow through AVF best predictor of thrombosis. The critical flow rate is different in PTFE grafts and AV fistulas. Fistulas that are most susceptible to thrombosis are those with a flow rate $<200 \mathrm{ml} / \mathrm{min}$. This is far less than what is needed for optimal blood flow during dialysis. As a result of low blood flow, dialysis will become ineffective and will result in recirculation ${ }^{49}$. Several procedures help identify critical low blood flow and upcoming stenosis: auscultation (high frequency noise at the site of stenosis), hand lift examination (collapse of poststenotic vein segment and permanent congestion of the prestenotic segment), prolonged bleeding after removal of the needle from the injection site and increased pressure in the venous supply during HD, particularly over a number of consecutive dialysis ${ }^{50}$. Central venous stenosis may be clinically asymptomatic before the creation of vascular access and become symptomatic only when the flow increases. If critical stenosis can not accommodate the increased flow rate, the result will be a run-off hands and cyanosis, as well as the creation of collateral in the wall of the chest. Stenosis of the central vein is typically the result of previous subclavian catheter, or may be the result of incorporation of a pacemaker and its wire, then primary thrombosis in patients with antiphospholipid antibodies and coagulation disorders, tumors pressure etc. One therapeutic option is to ligate anastomosis and use a second arm after a corresponding $\mathrm{X}$-ray image to exclude bilateral stenosis ${ }^{51-56}$.

\section{HyPOTHESIS AND Aim}

The hypothesis reads: „Arteriovenous fistula after renal transplantation often become non-functional or require ligation." The aims of this study are to investigate the proportion of kidney transplanted subjects with spontaneous thrombosis, planar "closure" of AVF (ligation) after TX, and the remaining proportion of AVFs still functional. Then investigate time after TX where there was a possible loss of AVF function, and finally determine the relationship between these outcomes of AVF with demographic characteristics of respondents (age, sex, time after TX).

\section{Methods}

The study is structured as a cohort historical research. The study was conducted at the Department of Nephrology, Department of Internal Medicine, Clinical Hospital Center Osijek April-May 2018, with the approval of the Department and the approval of the Ethics Committee for Research Faculty of Medicine Osijek at the University of Osijek. The study included all patients transplanted into KBC Osijek in the first 10 years of kidney TX $(2007-2017)$ at this hospital. Of the 123 patients, $57.7 \%$ were men. The median age of all patients at the time the study was 58 years, ranging from 34-79 years.AVF function data and events related to AVF (thrombosis, "closure" or ligation), as well as demographic characteristics (age characteristics, sex, time after TX) are taken from medical records.

\section{StATISTICAL PROCEDURES}

The data are presented descriptively and processed analytically. Nominal data are presented using absolute and relative frequencies. The numerical data are presented as medians and interquartile range. The distribution normality was tested by Kolmogorov-Smirnov test. Frequency differences were measured by the hi-squared test in the numerical variables of the asymmetric distribution with the Kruskal-Wallis test. Statistical significance was accepted at $\mathrm{P}<0.05$. Statistical analysis was performed using SPSS software (version 17.0).

\section{RESULTS}

The study was conducted on 123 patients, of whom 71 (57.7\%) were men and $52(42.3 \%)$ women. Functional AVF, just before TX, had $96(78 \%)$ patients, $77(80.2 \%)$ on the left hand. AVF after TX is currently functioning in 49 patients $(39.8 \%$ of all and $51 \%$ of patients with functional AVF just prior to TX) (median follow-up 3 years, interquartile range (IQR) $1-5$, from 0 to 10 ). AVF thrombosis had, at some point after TX, 22 (17.9\% of all) patients $(21.9 \%$ of those with functional AVF immediately before TX), and 25 (20.3\% of all, or $26 \%$ of those who had functional AVF just prior to TX). The most common cause of ligation was (for 18 patients, $75 \%$ who had ligation) cardiac overload (Table 1).

Glomerulonephritis and autosomal dominant polycystic kidney disease were the two most common causes of renal failure in transplant patients. These are followed by interstitial nephritis, diabetes, arterial hypertension and others (malignant disease, urinary abnormalities, vasculitis) (Table 2)

The time to thrombosis or ligation of AVF was median 2 years (IQR 0 - 3). The median age at TX was 52 years (IQR 47-58) ranging from 27 to 70 years (Table 3 ). The median age of all patients was 58 years, ranging from 34 to 79 . Twelve patients (9.8\%) had 2 or more renal TX-a. AVF is curently functioning 


\begin{tabular}{ll}
\multicolumn{1}{c}{ Gender } & \multicolumn{1}{c}{$\begin{array}{c}\text { Number }(\%) \\
\text { of respondents }\end{array}$} \\
\hline $\begin{array}{l}\text { Males } \\
\text { Females }\end{array}$ & $71(57,7)$ \\
\multicolumn{1}{c}{ AVF* before transplantation $^{*}$} & $52(42,3)$ \\
Yes & $96(78)$ \\
No & $27(22)$ \\
Total & $123(100)$ \\
\hline \multicolumn{1}{c}{ AVF* considering the hand } & $19(19,8)$ \\
Right arm & $77(80,2)$ \\
Left arm & $96(100)$ \\
\hline Total The reason for the ligation & $5(21)$ \\
Aneurysmatic dilatation & $18(75)$ \\
Cardiac overload & $1(4)$ \\
Hand oedema & $24(100)$ \\
Total &
\end{tabular}

in $49(39.84 \%)$ patients (Picture 1$)$.

In the post-transplant period until the time of this study, 13 $(10.6 \%)$ respondents died, most often due to a heart attack (4 patients, 3.3\%). Graft works or the patient died with a functioning graft in $107(87 \%)$ patients. Graft does not work or the patient died with graft by failed in $16(13 \%)$ patients. The patient is alive and graft works in $96(78 \%)$ patients. The patient is not alive or is not functioning graft in $27(22 \%)$ patients. (Table 4).

The fate of AVF significantly differed between men and women, so women had more often AVF thrombosis or ligation $(\bigotimes 2=7,948, P=0.047)$. In most women who had a functional AVF (36 out of 52) immediately before TX, there was

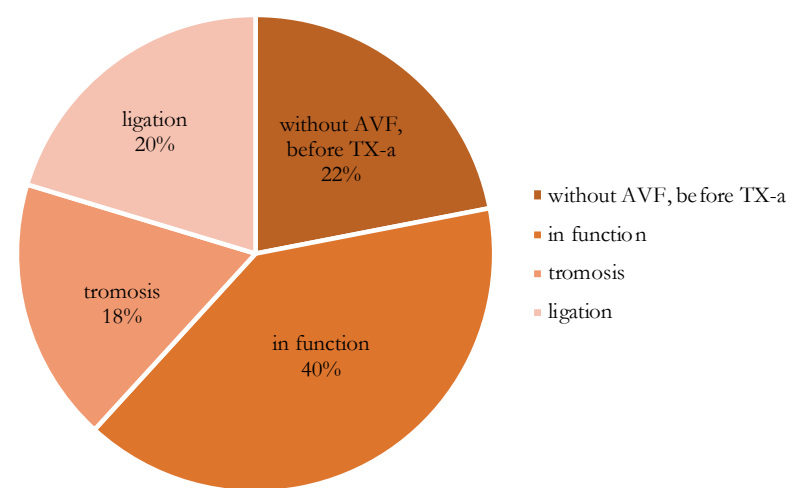

Picture 1. Distribution of patients with fate of arterial fistula (AVF) after renal transplantation (TX). AVF patients did not have functional AVF just before TX. Number provided below indicates the percentage of the absolute number of patients in the group.

\begin{tabular}{l|c}
\multicolumn{1}{c|}{ Basic kidney disease } & $\begin{array}{c}\text { Number }(\%) \text { of } \\
\text { respondents }\end{array}$ \\
\hline Glomerulonephritis & $56(45,5)$ \\
Autosomal dominant polycystic kidney disease & $22(17,9)$ \\
Diabetes & $13(10,6)$ \\
Arterial hypertension & $6(4,9)$ \\
Interstitial nephritis & $14(11,4)$ \\
Others & $12(9,8)$
\end{tabular}

a thrombosis (in 9) or AVF was ligated (in 13). In 60 out of 71 men AVF was functional just before TX, 13 of them was thrombosed and in 12 was ligated. Patients did not differ in age from AVF fate ( $\mathrm{P}=0.76$, Kruskal-Wallis test $)$.

\section{Discussion}

In our study of 123 patients with kidney transplant, AVF is currently functioning in $39.84 \%$ of patients (median follow-up 3 years), AVF thrombosis at some point after TX had $17.89 \%$ of patients, and their ligation $20.33 \%$. The most common cause of AVF ligation in our study was heart overload, for 18 patients (75\% of those who had a ligation). AVF after the renal TX has, therefore, often become dysfunctional, spontaneous or surgically closed.

In the research of Schier et al. there were 113 patients involved. In most patients it was necessary to close the AVF because of the onset of symptoms of heart overload, which corresponds to our results, which, in their study were caused by the rapid flow of blood through the AVF ${ }^{59}$. Since the blood flow is faster through the AVF, which are on the upper arms but the forearms ${ }^{60}$, so is the "closure" of AVF in the research of Schier et al. more often in those patients with AVFs on the upper arms. We do not have information on the exact localization of the AVF on hand for our patients and no data on the flow rate through the AVF. Vascular surgeons did not want to do the AVF ligation if there were no pathological findings in echocardiography in these patients, and the most common pathological findings on echocardiography were pulmonary hypertension and right ventricular dilatation ${ }^{59}$. Echocardiographic data for our patients were also not available. The assessment of cardiac load was mostly clinical. This and our research shows that the need to close AVF in patients with kidney stones is not uncommon ${ }^{59}$. Furthermore, studies by Unger and Van Dujnhover indicate that closure of the AVF ligation has a positive impact on the weight and diameter of the left ventricle ${ }^{57,58}$. Thus, AVF ligation in our patients due to cardiac overload is justified.However, the published reports are not unambiguous. Unger et al. in 17 transplant patients demonstrated that rapid blood flow through AVF favors the development of cardiac failure and death of the patient ${ }^{57}$.

Table 3. Age of transplantation patients (TX), time to thrombosis or arterial fistula ligation (AVF), dialysis time and duration of TX

\begin{tabular}{l|cc} 
& $\begin{array}{c}\text { Median } \\
\text { (interquartile range) }\end{array}$ & $\begin{array}{c}\text { Minimum }- \\
\text { maximum }\end{array}$ \\
\hline $\begin{array}{l}\text { Time after TX to thrombosis or ligation of AVF (year) } \\
(\mathrm{n}=47)\end{array}$ & $2(0-3)$ & $0-7$ \\
Time after TX to AVF Thrombosis (months) in the & $1(1-3)$ & $1-9$ \\
first year after TX (n = 12) & $3(1-5)$ & $0-14$ \\
Time on dialysis (years) & $3(1-5)$ & $0-9$ \\
Follow-up after TX (years) & $52(47-58)$ & $27-70$
\end{tabular}




\begin{tabular}{ll}
\hline The outcome & $\begin{array}{c}\text { Number }(\%) \text { of } \\
\text { respondents }\end{array}$ \\
Alive & $110(89,4)$ \\
Died & $13(10,6)$ \\
\hline The cause of death & $4(3,3)$ \\
Heart attack & $1(0,8)$ \\
Kidney carcinoma & $1(0,8)$ \\
Cytomegaloviral disease & $1(0,8)$ \\
Cardiac failure & $2(1,6)$ \\
Cholecystitis with sepsis & $1(0,8)$ \\
Unknown cause & $1(0,8)$ \\
Pulmonary embolism & $2(1,6)$ \\
Sepsis & $107(87)$ \\
Graft works or the patient died with a functioning graft & $16(13)$ \\
YES & $27(22)$ \\
NO & $96(78)$ \\
\hline Graft works and the patient is alive & $123(100)$ \\
NO &
\end{tabular}

Contrary to De Lima et al. and Meeus et al. show different results and claim that cardiac failure does not appear to be an AVF complication and that rapid blood flow through AVF for a longer period has a weak influence on morphology and heart function. They find that cardiac failure only occurs in those patients who already suffer from heart disease. It should be noted however that their studies were conducted on relatively young patients in the range of $33.4 \pm 12.5$ years who were generally in good condition without heart failure and had not been subjected to $\mathrm{TX}^{33,36}$. However, De Lima et al., comparing echocardiographic features in 39 transplanted patients with functional AVF and 21 patients with "closed" AVF, proved that "open" AVF can cause cardiac overload ${ }^{33}$. In the research conducted by Manca et al. in 365 transplanted patients with AVF, 42 (11.5\%) had AVF ligation due to aneurysmatic dilation, steal phenomena, infection, edema or aesthetic reasons ${ }^{28}$. A special case was described by Clarkson et al. in which AVF was the cause of high pulmonary arterial pressure and early decompensation of the right ventricle ${ }^{30}$. In our study of other reasons for the closure of AVF, except cardiac overload were aneurysmatic dilatation in $21 \%$ of them and hand oedema in $4 \%$ of patients, while in research conducted by Schier et al. only two ligation were related to flow, but one was due to aesthetic reasons and the other due to infection ${ }^{59}$.

Our study included all 123 patients who received a kidney transplant transplant in KBCO since in that hospital performs kidney TX (over a ten year period). The median age of all patients at the time of the study was 58 years, ranging from 34 to 79 years. In Leeja et al. the median age of all patients was 64 years, and $47 \%$ of them were older than 65 years. According to their study, no link was found between the age of patients over 65 and the number of AVF closures (ligations) ${ }^{61}$. Neither in our study of AVF fate after TX was not related to the age of the patient.

Miller et al. have shown that the incidence of thrombosis and other technical complications of AVF are more apparent in women than in men which is in line with our study in which AVF thrombosis or ligation was more common in women. Otherwise, this phenomenon that occurs more frequently in female patients in Miller et al., is not fully understood, but is considered to be related to the diameter of the blood vessels and the difficulty of expanding the veins under the pressure of the blood coming from the artery ${ }^{62}$.

In our study, the median time spent on dialysis was 3 years and $9.8 \%$ of patients had two or more TXs. In a study by Schier et al. the median time spent on dialysis was 3 years and 6 months, and $21.2 \%$ of patients had two or more TXs. Accordingly, no correlation was found between the number of TXs in patients and the number of AVF ligation, as well as a correlation between the time spent on dialysis and the need for AVF closure ${ }^{59}$. In our study, such a thesis was not proven. Among other things, Schier et al. consider that there is a link between faster need for "closure" of AVF with faster flow rate and reduced need for "closur" of AVF with slower blood flow $^{59}$. In our study, as noted above, no data were available on the rate of blood flow through the AVF.

The median time to AVF thrombosis or ligation in our participants was 2 years, while in 12 patients who experienced thrombosis during the first year, AVF usually stopped functioning as early as the first month. In a study by Schier et al., the median time to thrombosis or ligation of AVF was 2 years and 6 months, consistent with our result ${ }^{59}$.

Previous studies on the fate of AVF have been in the form of case reports or have been conducted in a small number of patients. This study, as well as the study conducted by Schier et al., may show success in the closure or ligation of AVF to prevent the development of cardiac overload, especially in individuals with rapid blood flow through AVF. An individual decision to close or not to close AVF must include all relevant factors, especially the function of the transplanted kidney, as well as the ability to create a new vascular approach in the event of graft rejection. Diseases such as anemia and hypertension can mask the symptoms of heart failure, therefore echocardiographic monitoring as well as other non-invasive procedures may be useful for timely intervention in the event of a potential development of cardiac overload caused by rapid flow through AVF ${ }^{59}$. In our patients, the assessment of heart overload caused by AVF has not been echocardiographically demonstrated.

\section{Conclusion}

Based on the results of the study, the following conclusions can be drawn: AVF before TX had $78 \%$ of patients, AVF is currently functioning in $39.84 \%$ of patients, and AVF was ligated or thrombosed in $38.22 \%$ of patients. Furthermore, the most common cause of AVF ligation in our study was cardiac overload, the time to thrombosis or ligation was median 2 years after TX, and if thrombosis occurred in the first posttransplant year, then it occurred at the median time 1 month after TX. And finally, AVF thrombosis or ligation was more common in women, and the fate of AVF after renal TX was not related to patient age.

In conclusion, AVF after renal TX often becomes dysfunctional, following spontaneous thrombosis or surgical ligation most 
commonly indicated by cardiac overload.

\section{AUTHOR CONTRIBUTIONS:}

All authors listed have made a substantial, direct and intellectual contribution to the work, and approved it for publication.

\section{LITERATURE:}

1. Kes, P.;Bašić Jukić, N.; Jurić I. 2006. Liječenje željezom bolesnika na dijalizi. Acta Medica Croatica. 60-457

2. Davidson, AM (ur.); Cameron, JS.; Grünfeld, JP.; Ponticelli, C.; Ritz, E.; Winearls, C.G. i sur. 2005. Oxford Textbook of Clinical Nephrology. III. izd. Oxford University Press. Oxford. 3. Jacobs, C.; Kjellstrand, CM.; Koch, KM.; Winchester, JF. 1996. Replacement of Renal Function by Dialysis. IV. izd. Kluwer Academic Pubs. Dordrecht - Boston - London.

4. Kes, P. i sur. 2006. Regulacija krvnog tlaka u bolesnika na dijalizi. Liječ Vjesn. 128-368

5. Levey, A.; Eckardt, K.; Tsukamoto, Y.; Levin, A.; Coresh, J.; Rossert, J. i sur. 2005. Definition and classification of chronic kidney disease: A position statement from Kidney Disease: Improving Global Outcomes (KDIGO). Kidney International. 67(6):2089-2100.

6. Webster, AC.; Bagler, E.V.; Morton, R. L.; Masson, P. 2017.Chronic kidney disease. Lancet. 389(10075):1238-1252.

7. Skorecki, K. i sur. 2005. Chronic renal failure. U: Kaspar, D.L. i sur. (ur.) Harrison's Principles of Internal Medicine. 15. Izd. McGraw-Hill.New York. 1653.

8. Kumar, P.; Clark, M. 2005.Clinical Medicine. 6. Izd. Elsevier-Saunders, Edinburgh. 665.

9. Levey ,A.S. i sur. 2005. National Kidney Foundation Practice Guidelines for Chronic Kidney Disease: Evaluation, Clasification. And Stratification. Ann Intern Med. 139-137.

10. Ivančević, Željko; Rumboldt, Zvonko; Bergovec, Mijo; Silobrčić, Vlatko. 2010. MSD (THE MERCK MANUAL OF DIAGNOSIS AND THERAPY) - priručnik dijagnostike i terapije. 2.hrvatsko izdanje.Split: PLACEBO.

11. Nankivell, B.J.; Chapman, J.R. 2006. Chronic allograft nephropathy: Current concepts and future directions. Transplatation. 81-643 12. Sollecito, T.P. 2006. Transplatacijska medicina. U: MS Greenberg. Ur. Glick, M. Burketova Oralna medicina. 10. Izd. Medicinska naklada. Zagreb. 503.

13. Referentni centar Ministarstva zdravstva i socijalne skrbi Republike Hrvatske za tipizaciju tkiva. Godišnje izvješće za 2005. godinu, lipanj 2006.

14. Ministarstvo zdravstva i socijalne skrbi RH. Projekti i programi: Transplatacijski program; Legislativa (2004): Nacionalne smjernice za transplataciju bubrega (2005).

15. Cohen, B.; Smits, J.; Haase, B.; Persijn, G.; Vanrenterghem, Y.; Frei, U. 2004. Expanding the donor pool to increase renal transplantation. Nephrology Dialysis Transplantation. 20(1)-34-41.

16. Danovitch, G.M. (ur.). 2005. Handbook of kidney transplatation. 4. Izd. Lipinccott, Williams and Wilkins Philadelphia.1.

17. Kes, P. i sur. 2005. Određivanje srčanožilnog rizika prije transplatacije bubrega. Liječ Vjesn. 127-330.

18. Macrae, J.M.; Pandeya, S; Humen, D.P;, Krivitski, N.; Lindsay, R.M. 2004. Arteriovenous fistula-associated high-output cardiac failure: a review of mechanism. Am J Kidney Dis. 43-17.

19. Clarkson, M.R.; Giblin, L.; Brown, A.; Little, D.; Donohoe, J.
2002. Reversal of pulmonary hypertension after ligation of a brachiocephalic arteriovenous fistula. Am J Kidney Dis.40-E8.

20. Swaroop, D.; Dimple, M. 2015. Comparative study to assess healthrelated quality of life among chronic kidney disease patients undergoing hemodialysis having arteriovenous fistula and venovenous vascular access. BFUNJ. 8(1).

21. Moist, L.M.; Lok, C.E.; Vachharajani, T.J.; Xi, W.; Al Jaishi, A.; Polkinghorne, K.R. i sur. 2012.Optimal vascular access in theelderly patient. Seminars in Dialysis. 25(6),640-648.

22. National Kidney Foundation (NKF). 2006. KDOQI clinical practice guidelines and clinical practice recommendations for 2006 updates: Vascular access.American Journal of Kidney Diseases. 48(Suppl. 1).S176 S322.

23. Besarab, A. 2004.Vascular access: Issues and management.Contributions to Nephrology. 142:29-46.

24. Burrows, L.; Kwun, K.; Schanzer, H.; Haimov, M. 1979.Haemodynamicdangers of high flow arteriovenous fistulas. Proc Eur Dial Transplant Assoc. 16:686-687.

25. Kinnaert, P.; Struyven, J.; Mathieu, J.; Vereerstaeten, P.; Toussaint, C.; Van Gerrstruyden, J. 1980.Intermittent claudication of the hand after creation of an arteriovenous fistula in the forearm. Am J Surg. 139:838-843.

26. Schanzer, H.; Schwartz, M.; Harrington, E.; Haimov, M. 1988 Treatment of ischaemia due to "steal" by arteriovenous fistula with distal artery ligation and revascularization. J Vasc Surg. 7:770-773. 27. Knox, R.C.; Berman, S.S.; Hughes, J.D.; Gentile, A.T.; Mills, J.L. 2002.Distal revascularization-interval ligation: A durable and effective treatment for ischemic steal syndrome after hemodialysis access. J Vasc Surg. 36:250-256.

28. Manca, O.; Pisano, O.L. 2005. Carta P et al. The management of hemodialysis arteriovenous fistulas in well functioning renal transplanted patients: many doubts, few certainties. J Vasc Access. 6-182. 29. Macrae, J.M.; Pandeya, S.; Humen, D.P.; Krivitski, N.; Lindsay, R.M. 2004. Arteriovenous fistula-associated high-output cardiac failure: a review of mechanism. Am J Kidney Dis. 43-17. 30. Clarkson, M.R.; Giblin, L.; Brown, A.; Little, D.; Donohoe, J. 2002. Reversal of pulmonary hypertension after ligation of a brachiocephalic arteriovenous fistula. Am J Kidney Dis.40-E8.

31. Kramar, R.; Oberbauer, R. 2010. Austrian Dialysis and Transplantation Registry (OEDTR). Annual Report. Austrian Society of Nephrology.

32. Al-ghonaim, M.; Manns, B.J.; Hirsch, D.J.; Gao, Z.; Tonelli, M. 2008. Relation between access blood flow and mortality in chronic hemodialysis patients. Clin J Am Soc Nephrol. 3-387.

33. De lima, J.J.G.; Campos Vieira, M.L.; Molnar, LJ.;Medeiros, C.J.; Ianhez, L.E.; Krieger, E.M. 1999. Cardiac effects of persistent hemodialysis arteriovenous access in recipients of renal allograft. Cardiology. 92-236.

34. Movilli, E.; Viola, B.F.; Brunori, G et al. 2010. Long-term effects of arteriovenous fistula closure on echocardiographic functional and 
structural findings in hemodialysis patients: a prospective study. Am J Kidney Dis. 55-682.

35. Acharya, S.; Banerjee, D.; Fronek, J.; Fossati, N.; Chemla, E.S. 2009. High-output cardiac failure following insertion of right femoral artery to left femoral vein ptfe graft for haemodialysis: a case report. Semin Dial. 22-462.

36. Meeus F, Kourilsky O, Guerin AP, Gaudry C, Marchais SJ, London GM. 2000. Pathophysiology of cardiovascular disease in hemodialysis patients. Kidney Int. 76S: 140.

37. Santoro D, Savica V, Bellinghieri G. 2010. Vascular access for hemodialysis and cardiovascular complications. Minerva Urol Nefrol. 62: 81 .

38. III. NKF-K/DOQI Clinical Practice Guidelines for Vascular Access: update 2000. American journal of kidney diseases: the official journal of the National Kidney Foundation. 2001.; 37(1 Suppl 1):S137 \pm 81 .

39. Owen, W.F.; Lowrie, E.G. 1998. C-reactive protein as an outcome predictor for maintenance hemodialysis patients. Kidney international. 1998.;54(2):627 \pm 36 .

40. Kaysen GA. 2001. The microinflammatory state in uremia: causes and potential consequences. Journal of the American Society of Nephrology: JASN. 12(7):1549 57 .

41. Schomig, M.; Eisenhardt, A.; Ritz, E. 2000. The microinflammatory state of uremia. Blood purification. 18 (4):327 \pm 32 .

42. Rao, M.; Guo, D.; Perianayagam, M.C.; Tighiouart, H.; Jaber, B.L.; Pereira, B.J. et al. 2005. Plasma interleukin-6 predicts cardiovascular mortality in hemodialysis patients. American journal of kidney diseases: the official journal of the National Kidney Foundation. 45(2):324 \pm 33 .

43. Hoshi, T.; Kitagawa, K.; Yamagami, H.; Furukado, S.; Hougaku, H.; Hori, M. 2005. Relations of serum high-sensitivity C-reactive protein and interleukin- 6 levels with silent brain infarction. Stroke; a journal of cerebral circulation. 36(4):768 72 .

44. Kobayashi, S.; Nagino, M.; Komatsu, S.; Naruse, K.; Nimura, Y.; Nakanishi, M. et al. 2003. Stretch-induced IL-6 secretion from endothelial cells requires NF-kappaB activation. Biochemical and biophysical research communications. 308(2):306 \pm 12 .

45. Klaus Konner, K.; Nonnast-Daniel, B.;Ritz, E. 2003.The Arteriovenous Fistula. JASN June 1, 2003 vol. 14 no. 61669-1680 46. Maga, P.; Krzanowski, M.; Kaczmarczyk, P.; Koscielniak, J.; Partyka, L.; Belowski, A et al. 2017. Endovascular treatment of dysfunctional arteriovenous fistula in hemodialyzed patients - the results of one year follow-up. Acta Angiologica. 22(4):143-149

47. Hong, Ding; Di, Gao. 2016. Analysis of arteriovenous fistula failure in hemodialysis patients. Biomedical Research. 27(2):396-400. 48. De Marchi, S.; Falleti, E.; Giacomello, R.; Stel, G.; Cecchin, E.; Sepiacci, G.; Bortolotti, N.; Zanello, F.; Gonano, F.; Bartoli, E. 1996. Risk factors for vascular disease and arteriovenous fistula dysfunction in hemodialysis patients. J Am Soc Nephrol. 7:1169-1177. 49. Tonelli, M., Hirsch, D.; Clark, T.W.I.; Wile, C.; Mossop, P.;
Marryatt, J.; Jindal, K. 2002. Access flow monitoring of patients with native vessel arteriovenous fistulae and previous angioplasty. J Am Soc Nephrol. 13:2969-2973.

50. Turmel-Rodrigues, L.; Pengloan, J.; Rodrige, H.; Brillet, G.; Lataste, A.; Pierre, D.; Jourdan, J-L.; Blanchard, D. 2000. Treatment of failed native arteriovenous fistulae for hemodialysis by interventional radiology. Kidney Int. 57: 1124-1140.

51. Schwab, S.J.; Quarles, L.D.; Middleton, J.P.; Cohan, R.H.; Saeed, M.; Dennis,V.W. 1988. Hemodialysis-associated subclavian vein stenosis. Kidney Int 33: 1156-1159.

52. Schillinger, F.; Schillinger, D.; Montagnac, R.; Milcent, T. 1991. Post catheterization vein stenosis in haemodialysis: Comparative angiographic study of 50 subclavian and 50 internal jugular accesses. Nephrol Dial Transpl. 1991.;6: 722-724.

53. Konner, K,.;Vorwerk, D. 1997.Permanent pacemaker wires causing subclavian vein stenosis in presence of AV fistula-Is it ever wrong to try angioplasty and stenting? Nephrol Dial Transplant. 12: 1735-1738. 54. Kovalik, E.C.; Newman, G.E.; Suhocki, P.; Knelson, M.; Schwab, S.J. 1994. Correction of central venous stenoses: Use of angioplasty and vascular Wallstents. Kidney Int 45. 1177-1181.

55. Vorwerk, D.; Guenther, R.W.; Mann, H.; Bohndorf, K.; Keulers, P.; Alzen, G.; Sohn, M.; Kistler, D.1995. Venous stenosis and occlusion in hemodialysis shunts: Follow-up results of stent placement in 65 patients. Radiology 195. 140-146.

56. Duncan, J.M.; Baldwin, R.T.; Caralis, J.P.; Cooley, D.A. 1991. Subclavian vein-to-right atrial bypass for symptomatic venous hypertension. Ann Thorac Surg 52. 1342-1343.

57. Unger, P.; Wissing, K.M.; De pauw L.; Neubauer, J.; Van de borne P. 2002. Reduction of left ventricular diameter and mass after surgical closure in renal transplant recipients. Transplantation. 74-73.

58. Van Duijnhoven ECM, Cheriex ECM, Tordoir JHM, Kooman JP, Van hooff JP. 2001. Effect of closure of the arteriovenous fistula on left ventricular dimensions in renal transplant patients. Nephrol Dial Transplant. 16-368.

59. Schier, T.; Gobel, G.; Bosmüller, C.; Gruber, I.; Tiefenthaler, M. 2013. Incidence of arteriovenous fistula closure due to high-output cardiac failure in kidney-transplanted patients. Clin Transplant. $27: 858-865$.

60. Huijbregts, H.J.; Bots, M.L.; Wittens, C.H.; Schrama, Y.C.; Blankestijn, P.J. 2009. Access blood flow and the risk of complications in mature forearm and upper arm arteriovenous fistulas. Blood Purif. $27-212$.

61. Lee, K.G.; Chong, T.T.; Goh, N.; Achudan, S.; Tan, Y.L.; Tan, R.Y.; Choong, H.L.; Tan, C.S. 2017. Outcomes of arteriovenous fistula creation, effect of preoperativevein mapping and predictors of fistula success in incidenthaemodialysis patients: A single-centre experience. Nephrology 22. 382-387.

62. Miller, C.D.; Robbin, M.L.; Allon, M. 2003. Gender differences in outcomes of arteriovenous fistulas in hemodialysis patients. Kidney Int. 63:346-52. 